Postgraduate Bosowa University Publishing (PBUP)
Indonesian Journal of Business and Management
e-ISSN: $2460-3767 \quad p$-ISSN: $2656-6885$
INttps://postgraduate.universitasbosowa
JOURAL

\title{
PENGARUH MOTIVASI PELAYANAN PUBLIK,PROFESIONALISME, TERHADAP KINERJA PEGAWAI MELALUI KEPUASAN KERJA DI KANTOR KECAMATAN BINAMU KABUPATEN JENEPONTO PROVINSI SULAWESI SELATAN
}

\author{
The Effect of Public Service Motivation, Professionalism on Employee Performance through Job Satisfaction at \\ the Binamu District Office, Jeneponto Regency \\ Jerry Alfreth $\mathbf{F}^{1}$, Muhlis Ruslan ${ }^{2}$, Chahyono ${ }^{2}$ \\ ${ }^{1}$ BKSDMPM Kabupaten Jeneponto \\ ${ }^{2}$ Program Studi Manajemen Program Pascasarjana Universitas Bosowa \\ Email: rcljery@gmail.com
}

Diterima: 24 Oktober 2021/Disetujui: 24 Desember 2021

\begin{abstract}
ABSTRAK
Penelitian ini bertujuan untuk mengetahui dan menganalisis pengaruh motivasi pelayanan publik, profesionalisme terhadap kinerja pegawai melalui kepuasan kerja. Populasi dalam penelitian ini adalah pegawai yang bekerja pada Kantor Kecamatan Binamu Kabupaten Jeneponto. Jenis penelitian yang dikemukakan adalah jenis penelitian kuantitatif, karena penelitian ini disajikan dengan angka-angka, teknik pengumpulan data melalui observasi, wawancara dan kuesioner, dengan teknik analisis data menggunakan analisis jalur. Hasil temuan dari penelitian ini adalah bahwa motivasi pelayanan publik dan profesionalisme berpengaruh secara nyata terhadap kepuasan kerja, dan kinerja pegawai, kepuasan kerja berpengaruh secara nyata dalam meningkatkan kinerja pegawai. Kepuasan kerja dapat memediasi secara parsial pengaruh motivasi pelayanan publik terhadap kinerja pegawai, Kepuasan kerja tidak dapat memediasi pengaruh antara profesionalisme terhadap kinerja pegawai, sedangkan profesionalisme hanya bepengaruh langsung terhadap kinerja pegawai
\end{abstract}

Kata Kunci: Motivasi Pelayanan Publik, Profesionalisme, Kepuasan Kerja dan Kinerja Pegawai

\section{ABSTRACT}

This study aims to determine and analyze the effect of public service motivation, professionalism on employee performance through job satisfaction. The population in this study were employees who worked at the Binamu District Office, Jeneponto Regency. The type of research proposed is a quantitative research type, because this research is presented with numbers. Data were collected through observation, interviews and questionnaires with data analysis techniques using path analysis. The results of this study are that public service motivation and professionalism have a significant effect on job satisfaction, and employee performance, job satisfaction has a significant effect on improving employee performance. Job satisfaction can partially mediate the effect of public service motivation on employee performance. Job satisfaction cannot mediate the effect of professionalism on employee performance, while professionalism only has a direct effect on employee performance.

Keywords: Public Service Motivation, Professionalism, Job Satisfaction and Employee Performance

This work is licensed under Creative Commons Attribution License 4.0 CC-BY International license

\section{PENDAHULUAN}

Era globalisasi sekarang ini maka salah satu faktor yang sangat menentukan keberhasilan atau kegagalan organisasi dalam mencapai tujuan adalah sumber daya manusia. Sumber daya manusia merupakan satu-satunya sumber daya yang memiliki akal, perasaan, keinginan, keterampilan, pengetahuan, dorongan, daya, dan karya (rasio, rasa dan karsa). Semua potensi sumber daya manusia tersebut berpengaruh terhadap upaya organisasi dalam mencapai tujuan. Betapapun majunya teknologi, perkembangan informasi, tersedianya modal dan 
memadainya bahan, jika tanpa SDM sulit bagi organisasi untuk mencapai tujuannya. Oleh karena itu merupakan sebuah tuntutan akan perbaikan kinerja setiap pegawai atau pemangku jabatan dalam organisasi publik. Organisasi yang berhasil dan efektif merupakan organisasi yang didalamnya memiliki sumber daya manusia atau pegawai yang dipandang sebagai salah satu aset organisasi yang penting dan perlu dikelola serta dikembangkan untuk mendukung kelangsungan hidup organisasi melalui kinerja yang dicapai. Kinerja merupakan hasil kerja yang mampu di peroleh pekerja, sebuah proses manajemen atau suatu organisasi secara keseluruhan, dimana hasil kerja tersebut dapat ditunjukkan buktinya secara nyata baik dari segi kualitas maupun kuantitas.

Kinerja pegawai merupakan kemampuan pegawai dalam melakukan sesuatu keahlian tertentu. Kinerja pegawai sangatlah perlu, sebab dengan kinerja ini akan diketahui seberapa jauh kemampuan pegawai dalam melaksanakan tugas yang dibebankan kepadanya. Untuk dapat mengoptimalkan kinerja pegawai maka perlunya kepuasan kerja pegawai. Handoko,T.Hani (2014) mengemukakan bahwa kepuasan kerja (job satisfaction) adalah keadaan emosional yang menyenangkan atau tidak menyenangkan dimana para pegawai memandang pekerjaan mereka. Kepuasan kerja mencerminkan perasaan seseorang terhadap pekerjaannya. Apabila karyawan puas maka akan nampak dalam sikap positif karyawan terhadap pekerjaannya agar dapat meningkatkan kinerja kerjanya. Kepuasan kerja merupakan prediktor kinerja, karena kepuasan kerja mempunyai korelasi moderat dengan kinerja. Tinggi rendahnya kepuasan kerja karyawan akan berpengaruh terhadap kinerja.

Ada beberapa faktor mempengaruhi kepuasan kerja dan kinerja pegawai pemerintahan yang salah satunya dan menjadi fokus penelitian ini adalah motivasi pelayanan publik. James L.Perry (2011) mengemukakan bahwa motivasi pelayanan publik sangat berpengaruh terhadap kinerja pegawai dalam mengabdikan dirinya kepada masyarakat karena salah satu bentuk atau bagian khas dari motivasi pelayanan publik adalah untuk mendorong seorang pekerja (pegawai) untuk mementingkan kepentingan organisasi, dan menyumbangkan darma baktinya kepada kesejahteraan organisasi dan masyarakat. Selain motivasi pelayanan publik, maka profesionalisme berpengaruh terhadap kinerja dan kepuasan kerja pegawai. Pegawai yang memiliki profesionalisme tinggi dapat memberikan kontribusi yang signifikan dalam pencapaian tujuan organisasi. Peneliti mengambil variabel kepuasan kerja sebagai variabel pemoderasi antara motivasi pelayanan publik, sebagaimana penelitian yang dilakukan oleh Amanda Rosalie (2017) dimana berdasarkan hasil pengujian menemukan bahwa motivasi pelayanan publik berpengaruh positif dan signifikan terhadap kinerja melalui kepuasan kerja, ini menunjukkan bahwa kepuasan kerja menjadi mediator pengaruh motivasi pelayanan publik terhadap kinerja pegawai. Begitu pula profesionalisme berpengaruh terhadap kinerja pegawai melalui kepuasan kerja, hal ini didasari dari penelitian Cahyasumirat (2006), hasil penelitian menunjukkan bahwa profesionalisme secara positif berpengaruh terhadap kepuasan kerja internal auditor namun tidak memiliki pengaruh positif terhadap kinerja. Sebagai gambaran awal akan disajikan data target dan realisasi pencapaian kinerja pada Kantor Kecamatan Binamu Kabupaten Jeneponto yang dapat dilihat melalui tabel berikut ini:

Tabel 1 Target dan Realisasi Pencapaian Kinerja Pegawai Kantor Kecamatan Binamu Kabupaten Jeneponto,2020

\begin{tabular}{|c|c|c|c|}
\hline $\begin{array}{c}\text { Bagian } \\
\text { (Unit Kerja) }\end{array}$ & Target & $\begin{array}{c}\text { Realisasi } \\
\text { Pencapaian } \\
\text { Target } \\
\text { Pertahun }\end{array}$ & $\begin{array}{c}\text { Persentase } \\
\text { Pencapaian } \\
\quad(\%)\end{array}$ \\
\hline Bagian Pemerintah & 6.375 & 5.288 & 85,43 \\
\hline $\begin{array}{l}\text { BagianPemberdayaan } \\
\text { Masyarakat Desa (PMD) }\end{array}$ & 10.487 & 5.643 & 63,77 \\
\hline Bagian Pelayanan Umum & 4.507 & 2.622 & 75,23 \\
\hline $\begin{array}{l}\text { Bagian Kesejahteraan } \\
\text { Sosial } \\
\text { (KESOS) }\end{array}$ & 5.644 & 3.178 & 71,89 \\
\hline $\begin{array}{l}\text { Bagian Keamanan dan } \\
\text { Ketertiban Umum } \\
\text { (Trantib) }\end{array}$ & 3.236 & 1.039 & 68,43 \\
\hline Bagian Perencanaan & 1.341 & 1.018 & 55,63 \\
\hline $\begin{array}{l}\text { Bagian Keuangan dan } \\
\text { Perlengkapan }\end{array}$ & 7.054 & 5.502 & 82,20 \\
\hline $\begin{array}{l}\text { Bagian Umum dan } \\
\text { Kepegawaian }\end{array}$ & 3.656 & 1.943 & 75,27 \\
\hline
\end{tabular}

Sumber : Kantor Kecamatan Binamu Kabupaten Jeneponto,2020

\section{METODE}

\section{a. Jenis Penelitian}

Jenis penelitian yang dikemukakan adalah jenis penelitian kuantitatif, karena penelitian ini disajikan dengan angka-angka. Hal ini sesuai dengan pendapat (Arikunto, 2014) yang mengemukakan penelitian kuantitatif yaitu penelitian yang banyak dituntut mengunakan angka, mulai dari pengumpulan data, penafsiran terhadap data tersebut, serta penampilan hasilnya. Penelitian kuantitatif yang bertujuan untuk mengetahui adanya hubungan antara variabel bebas dengan variabel terikat, dan variabel intervening dalam hal ini adalah .pengaruh motivasi pelayanan publik, profesionalisme terhadap kinerja pegawai melalui kepuasan kerja di Kecamatan Binamu Kabupaten Jeneponto

\section{b. Populasi dan Sampel}

Populasi dalam penelitian ini adalah pegawai pada Kantor Kecamatan Binamu Kabupaten Jeneponto berjumlah sebanyak 30 orang pegawai. menurut Sujarweni (2016) bahwa jika populasinya kurang dari 100 lebih baik diambil semua, sehingga penelitian ini merupakan penelitian populasi atau disebut sensus. Dari pendapat Sujarweni maka peneliti menentukan jumlah 
sampel sebanyak 30 Responden dari populasi yang ada, mengingat jumlah responden sedikit atau kurang dari 100 sehigga jumlah populasi yang ada dapat dijadikan sebagai jumlah keseluruhan sampel dalam penelitian ini.

\section{c. Variabel Penelitian}

Variabel penelitian terdiri atas 2 (dua) macam yaitu : Variabel terikat (dependent variabel) atau variabel yang tergantung pada variabel lainya, dan variabel bebas (independent variabel) atau variabel yang tidak tergantung pada variabel lainya. Variabel yang digunakan dalam penelitian ini adalah :

1) Variabel terkait yaitu kinerja pegawai dan kepuasan kerja.
a) Kinerja Pegawai (Y1)
b) Kepuasan kerja (Y2)

2) Variabel tidak terikat, yaitu :
a) Motivasi pelayanan publik (X1)
b) Profesionalisme (X2)

\section{d. Teknik Pengumpulan Data}

Untuk mendapatkan data yang diperlukan dalam rangka melakukan analisis terhadap pembuktian jawaban sementara atau hipotesis dari permasalahan yang dikemukakan maka peneliti menggunakan teknik pengumpulan data dengan cara sebagai berikut :

a. Wawancara

Wawancara adalah suatu cara untuk mendapatkan keterangan secara lisan dari responden. Teknik wawancara digunakan untuk melengkapi data yang diperoleh melalui angket dan dokumentasi.

b. Kuesioner

Kuesioner yaitu proses pengumpulan data melalui daftar pertanyaan yang disusun secara sistematis dan bersifat terbuka artinya responden memberikan jawaban berdasarkan pilihan jawaban yang telah disediakan. Penggunaan angket dimaksudkan agar semua jawaban yang diberikan responden lebih mudah untuk dinilai.

c. Studi pustaka

Bertujuan untuk melengkapi kekurangankekurangan yang terjadi dalam pengumpulan data yang berhubungan dengan teori-teori yang ada kaitannya dengan penelitian ini.

d. Dokumentasi

Dokumentasi yaitu pengumpulan data dengan mempelajari dokumen-dokumen pada Kantor Kecamatan Binamu Kabupaten Jeneponto menyangkut mengenai motivasi pelayanan publik, profesionalisme, terhadap kinerja pegawai melalui kepuasan kerja.

\section{e. Jenis dan Sumber Data}

Untuk mengumpulkan data dalam penelitian ini maka digunakan jenis dan sumber data sebagai berikut :

1. Jenis Data

a. Data Kualitatif yaitu data yang berupa keterangan-keterangan secara tertulis yaitu data yang diperoleh dalam bentuk informasi, melalui literatur, internet dan jurnal yang mendukung penelitian ini. b. Data Kuantitatif, yaitu data yang diperoleh dari hasil penyebaran kuesioner berupa angkaangka serta data lainnya yang menunjang penelitian ini.

2. Sumber Data

Adapun sumber data yang digunakan dalam penelitian ini bersumber dari data:

a. Dara primer yaitu data yang diperoleh melalui hasil wawancara dan daftar pernyataan, baik itu secara langsung maupun tidak langsung, pada pegawai di Kantor Kecamatan Binamu Kabupaten Jeneponto

b. Data sekunder yaitu data yang diperoleh dari berbagai sumber dokumen-dokumen atau laporan tertulis lainnya yang ada Pada Kantor Kecamatan Binamu Kabupaten Jeneponto.

\section{f. Teknis Analisis Data}

Teknik analisis data yang digunakan untuk menjawab hipotesis yang diajukan adalah :

1. Analisis deskriptif adalah suatu analisis yang menguraikan atau mengambarkan mengenai motivasi pelayanan publik, profesionalisme, kepuasan kerja dan kinerja pegawai melalui penyebaran kuesioner kepada sejumlah responden yang menjadi sampel dalam penelitian ini.

2. Uji instrument penelitian

Uji instrument yang digunakan dalam penelitian ini terbagi atas 2 bagian yakni :

a. Uji validitas digunakan untuk mengukur sah atau valid tidaknya suatu kuesioner. Uji validitas dilakukan dengan melakukan korelasi bivariate antara masing-masing skor indikator dengan total skor variabel.

b. Uji reliabilitas dimaksudkan untuk mengukur suatu kuesioner yang merupakan indikator dari variabel. Reliabilitas diukur dengan uji statistik cronbach's alpha $(\alpha)$. Suatu variabel dikatakan reliabel jika memberikan nilai cronbach' alpha > 0,60 .

3. Analisis jalur (path analysis) adalah suatu analisis untuk melihat sejauh mana pengaruh motivasi pelayanan publik, profesionalisme terhadap kinerja pegawai melalui kepuasan kerja pada Kantor Kecamatan Binamu Kabupaten Jeneponto dengan menggunakan rumus Asra, abuzar, dkk (2014) yaitu:

$$
\begin{aligned}
& \mathrm{Y} 1=\beta 0+\beta 1 \mathrm{X} 1+\beta 2 \mathrm{X} 2+\mathrm{e} \\
& \mathrm{Y} 2=\beta 0+\beta 1 \mathrm{X} 1+\beta 2 \mathrm{X} 2+\beta 3+\mathrm{Y} 1+\mathrm{e} \\
& \text { Keterangan : } \\
& \mathrm{Y} 1=\text { Kinerja pegawai } \\
& \mathrm{Y} 2=\text { Kepuasan kerja } \\
& \mathrm{b} 0=\text { Intercept } \\
& \mathrm{b} 1 \mathrm{~s} / \mathrm{d} \mathrm{b} 2=\text { Koefisien regresi yang akan } \\
& \mathrm{X} 1=\text { Motivasi pelayanan publik } \\
& \mathrm{X} 2=\text { Profesionalisme } \\
& \mathrm{e}=\text { Standar error. }
\end{aligned}
$$$$
\text { b1 s/d b2 = Koefisien regresi yang akan dihitung }
$$

4. Pengujian hipotesis dilakukan dengan menggunakan dua pengujian yakni uji $f$ (serempak) dan Uji $t$ (parsial) yang dapat diuraikan adalah : 
a. Uji t

Uji $\mathrm{t}$ digunakan untuk mengetahui apakah masing-masing variabel independen berpengaruh terhadap variabel dependen dalam regresi. Hipotesa yang digunakan dalam uji ini adalah :

Ho: Variabel independen tidak berpengaruh terhadap variabel dependen

Ha : Variabel independen berpengaruh terhadap variabel dependen

Dengan tingkat signifikan $(\alpha)$ sebesar $5 \%$, maka : Jika probabilitas $\mathrm{t}<\alpha$, berarti Ho ditolak

Jika probabilitas $t>\alpha$, berarti Ho diterima.

b. Uji f

Uji serempak (Uji f) digunakan untuk mengetahui apakah seluruh variabel bebasnya secara bersama-sama mempunyai pengaruh yang bermakna terhadap variabel terikat. Pengujian dilakukan dengan membandingkan nilai Fhitung dengan Ftabel pada derajat kesalahan 5\% $(\alpha=$ $0.05)$.

5. Koefisien determinasi (adjusted R2). Uji R2 merupakan uji yang dilakukan terhadap model yang dibentuk dengan tujuan menjelaskan seberapa besar kontribusi dari variabel bebas yang diteliti terhadap variabel terikat. Nilai $\mathrm{R} 2$ mempunyai range antara 0 sampai dengan $1(0 \leq \mathrm{R} 2 \geq 1)$. Semakin besar nilai R2 maka semakin bagus model regresi yang digunakan. Sedangkan semakin kecil nilai R2 artinya variabel bebas yang digunakan terhadap variabel terikat semakin kecil.

6. Uji Sobel Test

Untuk menguji pengaruh tidak langsung motivasi pelayanan publik dan profesionalisme terhadap kinerja pegawai melalui kepuasna kerja maka digunakan uji sobel test. Perhitungan dalam uji sobel test dilakukan dengan cara menguji kekuatan pengaruh tidak langsung variabel eksogen terhadap variabel endogen melalui variabel intervening. Rumus yang digunakan untuk menghitung standar error tidak langsung (indirect effect) dengan rumus yaitu :

Sp2p3 $=\sqrt{ } \rho 32 \mathrm{~S} \rho 22+\rho 22 \mathrm{~S} \rho 32+\mathrm{S} \rho 22 \mathrm{~S} \rho 32$

Untuk menguji signifikansi pengaruh tidak langsung variabel eksogen terhadap variabel endogen melalui intervening dengan rumus yaitu :

$$
\text { thitung = }
$$

Dimana :

$\mathrm{a}=$ Koefisien regresi variabel independent terhadap variabel mediasi

$\mathrm{b}=$ Koefisien regresi variabel mediasi terhadap variabel dependent

$\mathrm{Sa}=$ Standar error of estimated dengan pengaruh variabel independent terhadap variabel mediasi

$\mathrm{Sab}=$ Standar error tidak langsung (indirect effect)
$\mathrm{Sb}=\mathrm{Standar}$ error of estimated dan pengaruh variabel mediasi terhadap variabel independent terhadap variabel mediasi.

Nilai thitung dibandingkan dengan ttabel dan jika thitung lebih besar dari nilai ttabel maka dapat disimpulkan terjadi pengaruh mediasi. Untuk mengetahui pengaruh keputusan uji hipotesis dilakukan dengan cara membandingkan pvalue dan alpha $(0,05)$ dengan ketentuan sebagai berikut :

- Jika pvalue $\geq$ Alpha $(0,05)$ maka Ho diterima, Ha ditolak artinya tidak ada pengaruh signifikan pengaruh tidak langsung variabel eksogen terhadap variabel endogen melalui variabel intervening.

- $\quad$ Jika $\rho v a l u e ~ \leq$ Alpha $(0,05)$ maka Ho ditolak dan Ha diterima artinya ada pengaruh signifikan pengaruh tidak langsung variabel eksogen terhadap variabel endogen melalui variabel intervening.

\section{HASIL DAN PEMBAHASAN}

1) Pengaruh Kompetensi Terhadap Kepuasan Kerja Pegawai APIP Pada Kantor Inspektorat Kabupaten Barru Pengaruh Motivasi Pelayanan Publik Terhadap Kepuasan Kerja Pada Kantor Kecamatan Binamu Kabupaten Jeneponto

Hasil pengamatan yang telah dilakukan melalui analisi data motivasi pelayanan publik pada Kantor Kecamatan Binamu di Kabupaten Jeneponto yang menunjukkan motivasi pelayanan publik sudah berada dalam kategori cukup baik, alasannya karena setiap pegawai yang berkerja di kantor Kecamatan selalu dilibatkan dalam pembuatan kebijakan publik khususnya berkaitan dengan prosedur pelayanan pubik. Kemudian pegawai yang bekerja pada Kantor Kecamatan Binamu di Kabupaten Jeneponto menyadari pentingnya tanggung jawab dalam melayani publik.

Kemudian dari hasil jawaban responden memberikan indikasi bahwa pegawai yang bekerja pada Kantor Kecamatan Binamu Kabupaten Jeneponto memiliki rasa simpati kepada masyarakat walaupun tidak mendapatkan imbalan dan selain itu pegawai selalu mengorbankan waktunya demi untuk kepentingan masyarakat dan selalu mendahulukan tugas kantor untuk kepentingan masyarakat jeneponto. Dilihat dari hasil jawaban responden yang diperoleh melalui penyebaran kuesioner nampak bahwa skor yang terendah adalah keterlibatan pegawai dalam pembuatan kebijakan publik, sehingga upaya dalam meningkatkan kepuasan kerja pegawai maka perlunya ditingkatkan yakni dengan melibatkan pegawai saat membuat kebijakan publik.

Temuan penelitian ini menunjukkan bahwa dengan adanya motivasi pelayanan publik akan memberikan dampak terhadap peningkatan kepuasan kerja pegawai kantor kecamatan Binamu Kabupaten Jeneponto. Kemudian teori yang dikemukakan oleh Perry \& Wise 
(2011) bahwa motivasi pelayanan publik lebih mengutamakan usaha ekstra dalam menciptakan kinerja pegawai, sehingga jika pegawai merasa pekerjaan mereka berarti maka akan memberikan kepuasan publik dan memiliki dorongan untuk berkontribusi kepada masyarakat sehingga dari teori yang dikemukakan oleh Perry \& Wise (2011) telah sejalan yang ditemukan oleh peneliti.

\section{2) Pengaruh Profesionalisme terhadap Kepuasan Kerja}

Tanggapan responden mengenai profesionalisme terlihat bahwa setiap pegawai sudah memiliki pengetahuan, ketrampilan dan pengalaman yang cukup tinggi dalam bekerja, selain itu setiap pegawai sudah dapat menyelesaikan pekerjaanya dengan baik dan benar, pencapaian efektifitas kerja pegawai sudah dilaksanakan sesuai standar yang telah ditetapkan di tempat pegawai bekerja dan setiap pegawai yang bekerja pada Kantor Kecamatan Binamu Kabupaten Jeneponto sudah mengerjakan pekerjaannya sesuai dengan tanggungjawabnya. Berdasarkan hasil skor jawaban responden yang telah diamati bahwa skor yang terendah adalah kompetensi pegawai, hal ini perlu ditingkatkan guna dapat meningkatkan kepuasan kerja dan kinerja pegawai yang dilakukan dengan memberikan kesempatan kepada pegawai untuk mengikuti diklat. Sedangkan skor yang tertinggi adalah tanggung jawab pegawai dalam penyelesaian pekerjaan, sehingga perlu ditingkatkan untuk peningkatan kepuasan dan kinerja pegawai.

Temuan ini memberikan indikasi bahwa profesionalisme pegawai secara nyata dapat meningkatkan kepuasan kerja yang artinya pegawai professional dalam bekerja dapat menimbulkan kepuasan dalam bekerja. pendapat yang dikemukakan oleh Afandi.P (2018) bahwa keahlian dalam melakukan pekerjaan akan meningkatkan/mengurangi kepuasan kerja. Pendapat Afandi.P (2018) sesuai dengan yang ditemukan oleh peneliti. Penelitian yang dilakukan oleh Cahyasumirat (2006), hasil penelitian menunjukkan bahwa profesionalisme secara positif berpengaruh terhadap kepuasan kerja, sehingga dalam penelitian oleh Cahyasumirat (2006) telah sesuai dengan yang ditemukan oleh peneliti bahwa profesionalisme berpengaruh terhadap kepuasan kerja.

\section{3) Pengaruh Motivasi Pelayanan Publik Terhadap Kinerja Pegawai}

Berdasarkan hasil analisis data penelitian ini yang memberikan temuan bahwa motivasi pelayanan publik memberikan dampak secara nyata dalam meningkatkan kinerja pegawai. Hal ini dapat di indikasikan bahwa semakin besar motivasi yang dimiliki pegawai, khususnya dalam memberikan pelayanan publik maka akan dapat meningkatkan kinerja pegawai pada Kantor Kecamatan Binamu Kabupaten Jeneponto. Sehingga temuan penelitian menunjukkan bahwa dengan adanya dorongan pegawai dalam hal memberikan pelayanan kepada publik dapat memberikan hasil kerja yang lebih tinggi. pendapat yang dikemukakan oleh Afandi.P (2018) bahwa motivasi adalah keinginan yang timbul dari dalam diri seseorang atau individu karena terinspirasi, tersemangat dan terdorong untuk melakukan aktivitas dengan keikhlasan, senang hati dan sungguh sungguh sehingga aktivitas yang dilakukan mendapat hasil yang baik dan berkualitas. Pendapat yang dikemukakan oleh Afandi.P (2018) telah sejalan yang dilakukan oleh peneliti bahwa motivasi pelayanan publik mempengaruhi kinerja pegawai pada Kantor Kecamatan Binamu Kabupaten Jeneponto.

Pendapat yang dikemukakan oleh Perry \& Wise (2011) bahwa motivasi pelayanan publik lebih mengutamakan usaha ekstra dalam menciptakan kinerja pegawai, sedangkan dari beberapa peneliti sebelumnya yaitu Pardiman (2015), dan Atnila (2019) menemukan bahwa motivasi berpengaruh terhadap kinerja pegawai. Sehingga dari pendapat yang dikemukakan oleh Perry dan Wise (2011) dan beberapa peneliti sebelumnya telah sesuai dengan yang ditemukan oleh peneliti, bahwa motivasi pelayanan publik berpengaruh terhadap kinerja pegawai, dengan demikian dalam penelitian ini telah menguatkan teori mengenai hubungan motivasi pelayanan publik terhadap kinerja pegawai.

\section{4) Pengaruh Profesionalisme Terhadap Kinerja Pegawai}

Berdasarkan hasil pengamatan melalui penyebaran kuesioner kepada sejumlah pegawai khususnya pada Kantor Kecamatan Binamu Kabupaten Jeneponto.yang menunjukkan bahwa profesionalisme memberikan dampak dalam meningkatkan kinerja pegawai, hal ini dapat dikatakan bahwa semakin tinggi profesionalisme pegawai dengan pelaksanaan pekerjaan maka akan dapat meningkatkan kinerja kerjanya. dilihat dari masa kerja pegawai yang bekerja pada Kantor Kecamatan Binamu Kabupaten Jeneponto antara 6,1-10 tahun dan didukung dengan pendidikan terakhir pegawai yang rata rata sarjana (S.1) berarti pegawai sudah memiliki pengalaman yang cukup tinggi dan wawasan dalam melaksanakan pekerjaan yang menjadi tanggungjawabnya sehingga dapat memberikan dampak terhadap kinerja pegawai. Pendapat yang dikemukakan oleh Dwiyanto (2011) mengatakan paham atau keyakinan bahwa sikap dan tindakan aparatur dalam menyelenggarakan kegiatan pemerintahan dan pelayanan selalu didasarkan pada ilmu pengetahuan dan nilai-nilai profesi aparatur yang mengutamakan kepentingan publik.

Pegawai yang memiliki profesionalisme tinggi dapat memberikan kontribusi yang signifikan dalam pencapaian tujuan organisasi. Secara khusus, profesionalisme diharapkan dapat memberikan dampak bagi peningkatan kinerja pegawai. Sehingga dalam penelitian ini sesuai dengan temuan peneliti mengenai profesionalisme terhadap kinerja pegawai. Beberapa peneliti sebelumnya yakni Cahyasumirat (2006), Gerry Richard Bolung, (2018), dan Clara I.A Waterkamp, (2017) yang hasil 
penelitian menemukan bahwa profesionalisme berpengaruh signifikan terhadap peningkatan kinerja pegawai. Temuan penelitian ini mampu menguatkan teori bahwa profesionalisme berpengaruh terhadap kinerja pegawai.

\section{5) Pengaruh Kepuasan Kerja Terhadap Kinerja Pegawai \\ Berdasarkan hasil pengamatan yang telah dilakukan} yaitu jawaban responden mengenai kepuasan kerja pegawai yang bekerja pada Kantor Kecamatan Binamu Kabupaten Jeneponto yang berada dalam kategori cukup/sedang. Alasannya karena pegawai sudah merasa puas dengan gaji yang diterima karena sesuai dengan tugas dan tanggung jawabnya, sedangkan dilihat dengan kebijakan promosi (pangkat/jabatan) di tempat kerja sudah dirasakan puas oleh pegawai selain itu bahwa cara atasan dalam menilai prestasi kerja sudah memberikan kepuasan pegawai. Kemudian dalam hal pemberian tunjangan kerja yang diterima pegawai sudah sesuai dengan beban kerja pegawai sehingga memberikan kepuasan kerja bagi setiap pegawai pada Kantor Kecamatan Binamu di Kabupaten Jeneponto. Dan bagi pegawai yang berprestasi selalu mendapatkan penghargaan selain itu pekerjaan sesuai dengan keilmuan pegawai.

Skor jawaban responden yang terendah khususnya dalam hal kepuasan kerja adalah pemberian penghargaan bagi pegawai, hal ini perlu ditingkatkan guna meningkatkan kinerja pegawai sedangkan skor yang tertinggi adalah cara atasan dalam menilai prestasi kerja dan tunjangan kerja bagi pegawai yang bekerja pada Kantor Kecamatan Binamu Kabupaten Jeneponto sehingga perlu dipertahankan/ ditingkatkan guna meningkatkan kinerja pegawai. Kemudian dalam temuan penelitian melalui hasil analisis data maka kepuasan kerja memberikan dampak secara nyata dalam meningkatkan kinerja pegawai. Temuan penelitian ini memberikan hasil bahwa dalam meningkatkan kinerja pegawai dalam penyelesaian pekerjaannya maka perlunya pimpinan memperhatikan kepuasan kerja, alasanya karena ketidakpuasan pegawai dalam bekerja dapat diikuti oleh hasil kerja yang rendah dan tidak berkualitas. Hal ini didukung oleh Busro, Muhammad (2018:104) bahwa kepuasan kerja berpengaruh langsung terhadap kinerja, semakin tinggi kepuasan kerja maka hasil kerja dapat ditingkatkan. Sedangkan Afandi.P (2018:78) mengatakan bahwa kepuasan kerja menyebabkan peningkatan kinerja, sehingga pegawai yang puas akan lebih produktif. Di sisi lain kepuasan kerja disebabkan oleh adanya kinerja atau prestasi kerja, sehingga pegawai yang lebih produktif akan mendapatkan kepuasan. Dalam kaitannya dengan uraian tersebut di atas maka dari pendapat yang dikemukakan oleh Busro,Muhamad (2018) dan Afandi.P (2018) sesuai dengan yang ditemukan oleh peneliti.
6) Pengaruh Motivasi Pelayanan Publik Terhadap Kinerja Pegawai Melalui Kepuasan Kerja

Berdasarkan hasil analisis data penelitian mengenai hasil uji mediasi dengan menggunakan sobel test secara online maka diperoleh temuan dalam penelitian ini bahwa kepuasan kerja dapat memediasi secara parsial antara motivasi pelayanan publik terhadap kinerja pegawai. Alasannya karena secara empiris menunjukkan bahwa baik pengaruh langsung maupun tidak langsung motivasi pelayanan publik terhadap kinerja pegawai melalui kepuasan kerja khususnya pada Kantor Kecamatan Binamu Kabupaten Jeneponto.Temuan ini dapat diindikasikan bahwa secara empiris bahwa motivasi pelayanan publik dapat meningkatkan kepuasan kerja yang berdampak terhadap kinerja pegawai. Penelitian oleh Amanda (2017) mengatakan bahwa motivasi pelayanan publik terhadap kinerja pegawai melalui kepuasan kerja, menunjukkan bahwa kepuasan kerja menjadi mediator pengaruh motivasi pelayanan publik terhadap kinerja pegawai, sehingga dalam penelitian ini sejalan dengan yang dilakukan peneliti.

\section{7) Pengaruh Profesionalisme Terhadap Kinerja Pegawai Melalui Kepuasan Kerja}

Berdasarkan hasil analisis data penelitian melalui uji sobel test yang menunjukkan bahwa kepuasan kerja terbukti tidak dapat memediasi pengaruh profesionalisme terhadap kinerja pegawai pada Kantor Kecamatan Binamu Kabupaten Jeneponto melainkan hanya berpengaruh langsung terhadap kinerja pegawai. Hasil uji mediasi dalam penelitian ini maka dapat dikatakan bahwa kepuasan kerja merupakan full mediation antara profesionalisme terhadap kepuasan kerja, hal ini dapat dikatakan bahwa profesionalisme hanya berpengaruh langsung terhadap kinerja pegawai, dan secara tidak berpengaruh terhadap kinerja jika melalui kepuasan kerja. Alasannya karena dalam hal profesionalisme masih adanya pegawai yang merasa kurang dengan kompetensi seperti pengetahuan, ketrampilan dan pengalaman dalam melaksanakan pekerjaannya. Sehingga hal ini perlu ditingkatkan guna dapat memberikan kepuasan kerja bagi pegawai yang berdampak dalam meningkatkan kinerja kerjanya. Kemudian dalam hal kepuasan kerja bahwa masih adanya pegawai yang kurang puas dengan pemberian gaji, karena gaji yang diterima masih kurang sesuai dengan beban dan tanggung jawab yang diberikan kepada setiap pegawai khususnya pada Kantor Kecamatan Binamu di Kabupaten Jeneponto.

\section{KESIMPULAN DAN SARAN}

Hasil penelitian dapat disimpulkan bahwa motivasi pelayanan publik berpengaruh secara nyata terhadap Kepuasan Kerja pegawai kantor Kecamatan Binamu Kabupaten Jeneponto, Maka dapat disimpulkan bahwa rata-rata pegawai sudah memiliki rasa tanggung jawab serta rela berkorban untuk kepentingan masyarakat.Pengaruh Profesionalisme terhadap Kepuasan Kerja Pegawai pada kantor Kecamatan Binamu 
Kabupaten Jeneponto. Saran yang dapat diberikan Hendaknya setiap pegawai Kantor Kecamatan Binamu Lebih Meningkatkan partisipasi untuk terlibat langsung dalam hal penyusunan kebijakan publik khususnya pada lingkup Kantor Kecamatan Binamu di Kabupaten Jeneponto

\section{DAFTAR PUSTAKA}

Afandi, P. (2018). Manajemen Sumber Daya Manusia (Teori, Konsep dan Indikator). Riau: Zanafa Publishing.

Amanda, Rosalie (2017) Pengaruh Motivasi Pelayanan Publik Terhadap Kinerja Organisasi Melalui Kepuasan Kerja Pada Bagian Training Plan Dan Evaluation di PT Angkasa Pura II. Jurnal Fakultas Ekonomi dan Bisnis Universitas Trisakti, Jakarta

Arikunto, Suharsimi. 2014. Prosedur Penelitian Suatu Pendekatan Praktik. Penerbit : Rineka Cipta, Jakarta

Asra, Abuzar, dkk. (2014). Metode Penelitian Survey.Jakarta : In Medika

Atnila (2019) Pengaruh Motivasi Terhadap Kinerja Pegawai di Kantor Kelurahan Kawatuna. e Jurnal Katalogis, Volume 5 Nomor 4, April 2017 hlm 1-8. ISSN: 2302-2019.

Busro, Muhammad. 2018. Teori-Teori Manajemen Sumber Daya Manusia. Jakarta: Prenadameidia Group.

Cahyasumirat, Gunawan, (2006) Pengaruh Profesionalisme dan Komitmen Organisasi Terhadap Kinerja Internal Audit ordengan Kepuasan Kerja Sebagai Variabel Intervening (Studi Empiris Pada Internal Auditor PT. BANK ABC). Tesis Program Studi Magister Sains Akuntansi Program Pasca Sarjana Universitas Diponegoro Semarang

Clara I. A. Waterkamp, (2017) Pengaruh Profesionalisme, Komitmen Organisasi dan Kepuasan Kerja Terhadap Kinerja Karyawan pada PT. Bank Rakyat Indonesia (Persero) Cabang Manado. Jurnal EMBA, Vol.5 No.2 September 2017, Hal.2808-2818. ISSN 23031174.

Dwiyanto, Agus, 2011, Mengembalikan Kepercayaan Publik Melalui Reformasi Birokrasi, Penerbit : Gramedia Pustaka Utama. Jakarta

Gerry Richard Bolung, (2018) Pengaruh Profesionalisme dan Keterampilan Terhadap Kepuasaan Kerja Serta Dampaknya Terhadap Kinerja Pegawai Badan Perencanaan Pembangunan Daerah Provinsi Sulawesi Utara. Jurnal EMBA Vol.6 No.4 September 2018, Hal. 3238 - 3247 ISSN 2303-1174.

Handoko, T. Hani, 2014, Manajemen Personalia dan Sumberdaya Manusia, edisi revisi, Penerbit BPFE, Yogyakarta

James L. Perry and Annie Hondeghem. 2011. Motivational in Public Management. Oxford.

Pardiman (2015) Pengaruh Motivasi Kerja dan Budaya Organisasi Terhadap Kinerja Pegawai Pada Kantor
Pelayanan Publik. Jurnal Fakultas Ekonomi Universitas Islam Malang https://www.

Perry, James. L, Annie Hondeghem and Lois Recascino Wise. 2011. " Revisiting the Motivational Bases of Public Service: Twenty Years of Research and an Agenda for the Future". Paper prepared for presentation at the International Public Service.

Sujarweni, Wiratna, V. 2016, Kupas Tuntas Penelitian Akuntansi dengan SPSS, Penerbit : Pustaka Baru Press, Yogyakarta 